\title{
Associations between vegetative and production traits in guava tree full-sib progenies
}

\author{
Paulo Ricardo dos Santos(1), Sandra da Costa Preisigke ${ }^{(1)}$, Alexandre Pio Viana(1), \\ Natan Ramos Cavalcante(1), Carlos Misael Bezerra de Sousa ${ }^{(1)}$ and Antônio Teixeira de Amaral Júnior ${ }^{(1)}$ \\ (1)Universidade Estadual do Norte Fluminense Darcy Ribeiro, Laboratório de Genética e Melhoramento de Plantas, Avenida \\ Alberto Lamego, oㅡ 2.000, Parque Califórnia, CEP 28013-602 Campos dos Goytacazes, RJ, Brazil. E-mail: prs_ufal@hotmail.com, \\ sandrapreisigke@hotmail.com, natancavalcante2@hotmail.com, carlos.misael@outlook.com, pirapora@uenf.br, amaraluenf@gmail.com
}

\begin{abstract}
The objective of this work was to estimate the genetic parameters and to evaluate the associations between vegetative and yield characteristics, in full-sib progenies of guava tree (Psidium guajava). The following characteristics were evaluated: yield per plant, number of fruits, fruit mass, plant height, stem diameter, and canopy volume. The estimation of genetic parameters was obtained by the REML/Blup procedure. Based on the breeding values predicted by Blup, the genetic and canonical correlations were estimated, and the genetic correlation coefficients were unfolded into direct and indirect effects on the character yield per plant using path analysis. Genetic variability was estimated for number of fruits (567.66) and yield per plant (11.818), with high genetic correlation (0.9045), indicating simultaneous selection. Indirect selection did not promote simultaneous gains for yield per plant with the primary components number of fruits and fruit mass, making it difficult to obtain guava cultivars with high yield, number of fruits, and fruit mass. The vegetative traits had little effect on yield, number of fruits, and fruit mass.
\end{abstract}

Index terms: Psidium guajava, correlations, path analysis, REML/Blup.

\section{Associações entre características vegetativas e de produção em progênies de irmãos completos de goiabeira}

\begin{abstract}
Resumo - O objetivo deste trabalho foi estimar os parâmetros genéticos e avaliar as associações entre características vegetativas e de produção em progênies de irmãos completos de goiabeira (Psidium guajava). Avaliaram-se as seguintes características: produção por planta, número de frutos, massa de frutos, altura da planta, diâmetro de caule e volume de copa. A estimativa de parâmetros genéticos foi obtida com o procedimento REML/Blup. Com base nos valores genéticos preditos pelo Blup, estimaram-se as correlações genéticas e canônicas, e realizou-se o desdobramento dos coeficientes de correlação genética em efeitos diretos e indiretos sobre a característica produção por planta, com análise de trilha. Estimou-se variabilidade genética para número de frutos $(567,66)$ e produção por planta $(11,818)$, com alta correlação genética $(0,9045)$, o que evidencia seleção simultânea. A seleção indireta não promoveu ganhos simultâneos para produção por planta a partir dos componentes primários número de frutos e massa de frutos, o que dificulta a obtenção de cultivares de goiabeira com alta produção, número de frutos e massa de fruto. As características vegetativas apresentaram pouca influência na produção, no número de frutos e na massa de frutos.
\end{abstract}

Termos para indexação: Psidium guajava, correlações, análise de trilha, REML/Blup.

\section{Introduction}

Guava tree (Psidium guajava L.) is a tropical fruit tree widely distributed in several regions of the world, mainly in the American continent and in Australia (Campos et al., 2013). In 2013, guava production in Brazil reached $349,615 \mathrm{Mg}$, with the use of 14,982 ha of planted area, according to the Produção... (2013), which makes the country one of the world's largest guava producers, together with India and Mexico.
A large amount of guava cultivars in the country was obtained through selection carried out by farmers or research institutions, using plants from open pollinated orchards, where the superior traits of the selected plants were fixed by asexual propagation (Pommer et al., 2006; Campos et al., 2013). Thus, there is need for research seeking to improve selection efficiency in the genetic breeding of this species in Brazil, to increase productivity, fruit quality, and the traits of interest related to the plant, due to the increasing demand of 
guava by the processing and juice bottling industries (Campos et al., 2013).

To obtain gains in the selection of superior genotypes, it is important to know both the genetic variability available in the species and in the associations of traits to develop agronomically desirable genotypes (Oliveira et al., 2010). The phenotypic correlations were related to genetic and environmental causes, but only the genetic ones include an association with heritability, which can thus be used to obtain successful breeding programs (Cruz et al., 2012).

The correlations between vegetative traits and the traits of guava production components have not been elucidated yet. They are fundamental to determine selection strategies for crop breeding. However, the magnitude and value of the correlations are not enough to clarify the relationships between the traits, since there may not be a cause and effect relationship between them. The studies on correlation coefficient splitting use path analysis for splitting the effects of the variables studied on a main variable into direct and indirect effects, which can be carried out based on genetic, environmental or phenotypic correlations (Cruz et al., 2012).

Another important biometric procedure in studies on associations between variables is the use of canonical correlations, which make it possible to achieve even greater gains, compared to simultaneous selection, since they are not limited to the analysis of only two traits or explanatory variables in relation to a main one. Rather, they allow selecting groups of traits. It is possible, for example, to make a comparison between agronomic and vegetative traits, or even agronomic and fruit quality traits, which allows for a wide application in plant breeding (Bezerra Neto et al., 2006).

Both the trail analysis and canonical correlations are more effective when based on predicted genotypic values than on phenotypic values. When the genotypic values are predicted by the mixed model method (REML/Blup procedure), they provide more precise and accurate inferences, which increases the efficiency of the breeding programs. By means of the Blup (best linear unbiased prediction), phenotypic values are corrected for environmental effects and are weighted by the heritability of the trait, which is estimated by REML procedure (restricted maximum likelihood) (Patterson \& Thompson, 1971; Henderson, 1975).
The mixed models method has been used to generate information on breeding programs targeting perennial species, such as sugarcane (Silva et al., 2009), papaya (Oliveira et al., 2010), açaí palm (Teixeira et al., 2012) and juçara palm (Marçal et al., 2015). However, there is a lack of information on guava tree breeding.

The objective of this work was to estimate the genetic parameters and to evaluate the associations between vegetative and yield characteristics, in full-sib progenies of guava tree.

\section{Materials and Methods}

This work was conducted in the experimental area of Colégio Agrícola Antônio Sarlo, located in the municipality of Campos dos Goytacazes, in the state of Rio de Janeiro, Brazil (21 ${ }^{\circ} 44^{\prime} \mathrm{S}, 41^{\circ} 19^{\prime} \mathrm{W}$, at an altitude of $12 \mathrm{~m}$ ). Seventeen full-sib progenies were evaluated, which were obtained from biparental controlled crosses of individuals from a small farm called Providência, in the municipality of Bom Jesus do Itabapoana, also in the state of Rio de Janeiro, which belong to the germplasm bank of Universidade Estadual do Norte Fluminense Darcy Ribeiro (Uenf). For the controlled crosses, nine parents were selected by the genetic diversity analysis based on the random amplified polymorphic DNA (RAPD) marker (Pessanha et al., 2011).

The full-sib progenies were planted in June 2009, and the plants were arranged in a complete randomized block design, with spacing of $1.5 \mathrm{~m}$ between plants and $3.0 \mathrm{~m}$ between rows, and two replicates. The plots consisted of 8 to 23 plants, and a total of 323 guava tree genotypes were evaluated.

The first crop occurred in 2011, and data were collected in the fourth crop, between September and December 2014. All plants received the recommended crop cultivation treatments, such as plant management, fertilization, irrigation, weed control, and control of pests and diseases, in compliance with Natale (2009).

The following traits were evaluated: number of fruits per plant (NFP), counted in each individual, in all harvests; production per plant (PP), corresponding to the total mass of fruits per plant obtained using a semi-analytical balance and expressed in grams; fruit mass (FM), corresponding to average mass of fruits per plant, obtained using a semi-analytical balance and expressed in grams; plant height (PH), determined with a measuring tape and expressed in meters; stem 
diameter (SD) at $10 \mathrm{~cm}$ from the ground, which was measured with the aid of a digital caliper and expressed in centimeters; and volume of the canopy (VOLC), for which the height and mean radius of the plant were obtained from the canopy diameter, in the direction of the line and the interline, using the following expression: $\mathrm{V}\left(\mathrm{m}^{3}\right)=2 / 3 \pi \mathrm{R}^{2} \times \mathrm{H}$, in which $\mathrm{R}$ is the radius (m); and $\mathrm{H}$ is the height (m) (Souza et al., 2009).

The data analysis was performed using the REML/ Blup method, through the model that allows evaluating individuals in full-sib progenies. The experimental design was a complete randomized block design with 8 to 23 plants per plot, described in the matrix form, according to Resende (2007), by the equation: $\mathrm{y}=\mathrm{Xr}+\mathrm{Zg}+\mathrm{Wp}+\varepsilon$, in which $\mathrm{y}$ is the data vector; $\mathrm{r}$ is the vector of the replicate effects (considered fixed) added to the overall average; $g$ is the vector of individual genotypic effects (considered random); $\mathrm{p}$ is the vector of plot effects; $\varepsilon$ is the vector of errors or residuals (random); and $\mathrm{X}, \mathrm{Z}$, and $\mathrm{W}$ are known incidence matrices, formed by the values 0 and 1 , which associate the unknowns $r, g$, and $p$ with the data vector $y$, respectively. The following components of variance (individual REML) were estimated: $\sigma_{\mathrm{g}}^{2}$, genotypic variance between full-sib progenies, equivalent to $1 / 2$ of the additive genetic variance plus $1 / 4$ of the dominance genetic variance, disregarding epistasis; $\sigma^{2}$, individual phenotypic variance; $h^{2}{ }_{a}=h^{2}$, narrow-sense individual heritability, obtained without the fraction (1/4) of the dominance genetic variance; $\mathrm{h}^{2}$ ap , heritability based on the average progenies, in which complete survival was considered; $A c_{\text {prog}}$, accuracy of progeny selection, with complete survival; $\mathrm{h}^{2}$ ad, additive heritability within the plot, obtained without the fraction (1/4) of the dominance genetic variance and overall average of the experiment.

After obtaining the averages corrected by the Blup procedure, the genetic correlations were estimated based on the genotypic values $(\mathrm{u}+\mathrm{g})$ among the evaluated traits (Resende, 2016). The genetic correlations were the basis for the multicollinearity diagnosis, so as to verify the existence of multicollinearity, proposed by Montgomery \& Peck (1981), and avoid overestimation of the path coefficients (Cruz et al., 2012).

Path analysis was performed based on the genetic correlations matrix, with a least squares estimator (Cruz et al., 2012). Two chains were considered for the realization of the causal diagram in the decomposition of the genetic relationships between production per plant, considered the main variable, and the primary components (number of fruits and fruit mass) and secondary components (plant height, stem diameter and canopy volume), under different direct and indirect effects. Based on the estimates of the direct and indirect effects on the main variable production per plant, this study sought to verify if the high magnitude of the genetic correlations between the basic variables and the main variable was due to the indirect contribution of one or more primary or secondary variables.

The canonical correlations were estimated between the group of reproductive traits (production per plant, number of fruits, and fruit mass) and the group of vegetative traits (plant height, stem diameter, and canopy volume). The maximum correlation between linear combinations of the traits distributed in the two groups and the weighting coefficients of the traits in each linear combination were also determined.

The analyses were performed using the softwares Selegen (Resende, 2016) and Genes (Cruz, 2013).

\section{Results and Discussion}

The estimated values for genotypic variance ranged from 567.66 to 0.0001 (Table 1). The highest values were obtained for the traits number of fruits and production per plant (567.66 and 11.818, respectively), which indicates that the evaluated population has high genetic variability for these traits. Therefore, individual selection, due to genetic control, causes an increase in the frequency of favorable alleles in the genotypes with greater yield and number of fruits. Knowledge about genotypic variance is fundamental in breeding programs, since it indicates the range of genetic variation of a trait, in view of the possibility of breeding (Cruz et al., 2012).

Fruit mass, plant height, canopy diameter and canopy volume obtained the lowest values, from 0.243 to 0.0001 . Therefore, genetic gains with individual selection will be lower for these traits, which are more affected by the environment. This can be confirmed by the low estimates of the restricted individual heritabilities, based on the average progenies, and by the fact that the highest proportion of the phenotypic variance is attributed to the environmental variance. Highest individual heritability estimates for these traits, besides very low ones, were obtained by Pelea

Pesq. agropec. bras., Brasília, v.52, n.5, p.303-310, maio 2017 DOI: $10.1590 / \mathrm{S} 0100-204 X 2017000500003$ 
et al. (2012), when evaluating three populations of guava tree in Cuba. These results demonstrate the need to investigate traits that are less affected by the environment and affect fruit production, in order to allow obtaining indirect genetic progress.

Estimates ofnarrow-senseindividualheritability $\left(\mathrm{h}^{2}{ }_{\mathrm{a}}\right)$ ranged from 0.38 to 0.01 (Table 1). The highest values were obtained for production per plant and number of fruits ( 0.37 and 0.38 , respectively). Significantly higher values were observed for heritability compared to the average progenies ( $\left.h^{2} a p\right)$. The highest estimates for $h^{2}$ ap were observed for production per plant, number of fruits and fruit mass $(0.84,0.90$, and 0.41 , respectively). Under such conditions, selection can be more effective with the use of information from the full-sib progenies, since genotypes with these traits can obtain gains in production per plant, number of fruits and fruit mass, suitable not only for fresh food market, but also for the industrial sector (Campos et al., 2013; Santos et al., 2015).

Estimates of $\mathrm{h}^{2}{ }_{\mathrm{a}}$ and $\mathrm{h}^{2}$ ap for production per plant and number of fruits indicate that successful selection can be obtained both between and within progenies, respectively. However, high individual heritability, related to inheritable additive effects, shows that individual selection can be effective in selecting superior segregating genotypes (Santos et al., 2015).

The quality of the genotype assessment should be inferred preferably based on selective accuracy. In the present study, the accuracy values ranged from 0.90 to 0.13 . The highest values were obtained only for production per plant (0.84) and number of fruits (0.90), while the other traits obtained values below 0.41 (Table 1). According to Resende \& Duarte (2007), accuracy above $90 \%$ is only possible for traits with high heritability, as observed for number of fruits. Santos et al. (2015) evaluated interspecific hybrids of passion fruit and also found an accuracy value above 0.90 for number of fruits, which corroborates the results obtained in the present work. Accuracy values higher than 0.70 are sufficient for a precise inference about the genetic value of progenies. Since it is a measurement associated with precision in selection, accuracy is the main element of genetic progress that can be changed by breeders to maximize genetic gain (Viana \& Resende, 2014).

The highest estimates of genetic correlations were observed for number of fruits and production per plant (0.9045); and plant height and canopy volume (0.8931) (Table 2). Therefore, it is possible to obtain gains with correlated responses in production per plant and greater number of fruits, as well as in plant height and canopy volume. According to Falconer \& Mackay (1996), high correlations can result from pleiotropism, in which the same gene affects the expression of more than one trait. This information is useful for plant breeding, since it favors the simultaneous selection of two or more traits by selecting in only one of them. However, the other relationships between the traits had weak correlations $\left(\mathrm{r}_{\mathrm{g}}<0.54\right)$.

In all combinations of the vegetative traits studied, the genetic correlations were positive, which indicates that the selection for the improvement of one trait causes positive gain in the other variable too. The highest genetic correlation occurred between the traits plant height and canopy volume (0.8931), while the lowest correlation values were found between the traits plant height and stem diameter (0.5343), and

Table 1. Estimates of the following genetic parameters: genotypic variance between guava (Psidium guajava) progenies $\left(\sigma_{\mathrm{g}}^{2}\right)$, individual phenotypic variance $\left(\sigma_{\mathrm{p}}^{2}\right)$, individual heritability in the narrow sense $\left(\mathrm{h}_{\mathrm{a}}^{2}\right)$, heritability based on the average progenies $\left(\mathrm{h}^{2}{ }_{\mathrm{ap}}\right)$, progeny selection accuracy $\left(\mathrm{Ac}_{\mathrm{prog}}\right)$, and additive heritability within plot $\left(\mathrm{h}^{2}\right.$ ad $)$, obtained by the restricted maximum likelihood (REML) procedure, and average, for the production and vegetative traits in guava tree.

\begin{tabular}{|c|c|c|c|c|c|c|}
\hline $\begin{array}{l}\text { Genetic } \\
\text { parameters }\end{array}$ & $\begin{array}{c}\text { Production } \\
\text { per plant }(\mathrm{g})\end{array}$ & $\begin{array}{l}\text { Number } \\
\text { of fruits }\end{array}$ & $\begin{array}{c}\text { Average fruit } \\
\text { mass }(\mathrm{g})\end{array}$ & $\begin{array}{c}\text { Plant height } \\
\text { (m) }\end{array}$ & $\begin{array}{c}\text { Canopy diameter } \\
(\mathrm{cm})\end{array}$ & $\begin{array}{c}\text { Canopy volume } \\
\left(\mathrm{m}^{3}\right)\end{array}$ \\
\hline$\sigma_{\mathrm{g}}^{2}$ & 11.818 & 567.66 & 0.0001 & 0.0010 & 0.243 & 0.027 \\
\hline$\sigma_{p}^{2}$ & 63.890 & $3,059.35$ & 0.003 & 0.161 & 96.672 & 8.224 \\
\hline $\mathrm{h}^{2}{ }_{\mathrm{a}}$ & $0.37 \pm 0.13$ & $0.38 \pm 0.15$ & $0.06 \pm 0.05$ & $0.03 \pm 0.02$ & $0.01 \pm 0.01$ & $0.01 \pm 0.01$ \\
\hline $\mathrm{h}_{\text {ap }}^{2}$ & 0.84 & 0.904 & 0.412 & 0.028 & 0.033 & 0.019 \\
\hline $\mathrm{Ac}_{\text {prog }}$ & 0.916 & 0.951 & 0.642 & 0.166 & 0.182 & 0.137 \\
\hline $\mathrm{h}^{2}{ }_{\mathrm{ad}}$ & 0.237 & 0.2284 & 0.029 & 0.013 & 0.002 & 0.004 \\
\hline Average & 12.68 & 78.81 & 171.70 & 3.31 & 91.46 & 11.82 \\
\hline
\end{tabular}

Pesq. agropec. bras., Brasília, v.52, n.5, p.303-310, maio 2017

DOI: 10.1590/S0100-204X2017000500003 
canopy volume and stem diameter (0.4172), in which the selection of tall plants tends to lead to greater stem diameter and canopy volume. However, selection for increasing any of the three traits directly decreases the traits production per plant, number of fruits and fruit mass. Although the three vegetative traits have negative correlations with production, number of fruits and fruit mass, they were of low magnitude. Therefore, selection that favors production would not cause sharp decline in the vegetative traits.

Genetic correlations can be very useful in the presence of traits with low heritability and/or difficult to measure, because under these conditions, indirect selection can be carried out, provided that cause and effect is detected in the correlations studied. Therefore, the type of genetic correlation in breeding programs should be known and estimated (Falconer \& Mackay, 1996; Cruz et al., 2012).

The multicollinearity diagnosis based on genetic correlations provided the number of conditions (NC) of 139.15, and the multicollinearity was ranked as moderate (Montgomery \& Peck, 1981). Consequently, the tracking correlation coefficients were not overestimated in the present work. Thus, no variable was discarded. Only severe multicollinearity overestimates both the values of the simple correlation coefficients and the direct effects on the basic variable estimated by path analysis (Coimbra et al., 2005).

It was verified that the primary component number of fruits had the greatest direct effect (1.0795) on total fruit production, but low indirect negative effect on fruit mass (-0.4749) (Table 3). According to Cruz et al. (2012), simultaneous selection of traits targeting direct effects whose magnitudes are high may result in gains in the main variable. The direct effect of fruit mass on production per plant was 0.3979 , and a negative effect was observed on number of fruits (-0.077). This result indicates that direct selection in genotypes with greater number of fruits or fruit mass increases production per plant. However, indirect selection will not be efficient in promoting simultaneous gains for production per plant for these two primary components, which makes it difficult to obtain a variety of guava with high rates for fruit production, number of fruits and fruit mass. To overcome this difficulty, it is suggested that the simultaneous gains in the three traits can be achieved by selection index strategies (Viana \& Resende, 2014; Cabral et al., 2016).

Successful use of tracking coefficients is directly related to the composition of the causal diagrams, which should be carried out with breeders' knowledge about which variables are the most important in the expression of the main variable (Silva et al., 2009). It can be observed that the used diagram explained $94.58 \%\left(\mathrm{R}^{2}\right)$ of the variation in fruit production (Table 3).

Regarding secondary effects, plant height had the only positive direct effect $(0.4401)$ on production per plant (Table 4). The other traits showed a very low and negative direct effect on the main variable, as well as

Table 2. Genotype correlation coefficients between production and vegetative traits in guava tree (Psidium guajava).

\begin{tabular}{|c|c|c|c|c|c|}
\hline Trait & Production per plant & Fruit mass & Plant height & Stem diameter & Canopy volume \\
\hline Number of fruits & 0.9045 & -0.4399 & -0.0785 & -0.3009 & -0.1362 \\
\hline Production per plant & & -0.0770 & -0.0692 & -0.2316 & -0.1220 \\
\hline Fruit mass & & & 0.0228 & 0.0845 & 0.1319 \\
\hline Plant height & & & & 0.5343 & 0.8931 \\
\hline Stem diameter & & & & & 0.4172 \\
\hline
\end{tabular}

Table 3. Estimates of the direct and indirect effects of the primary components number of fruits and fruit mass on the main characteristic production per plant in guava tree (Psidium guajava).

\begin{tabular}{|c|c|c|c|c|}
\hline \multirow[t]{2}{*}{ Trait } & \multirow[t]{2}{*}{ Direct effect } & \multicolumn{2}{|c|}{ Indirect effect } & \multirow[t]{2}{*}{ Total } \\
\hline & & Number of fruits & Fruit mass & \\
\hline Number of fruits & 1.0795 & - & -0.1750 & 0.9045 \\
\hline Fruit mass & 0.3979 & -0.4749 & - & -0.077 \\
\hline $\mathrm{R}^{2}$ & 0.9458 & & & \\
\hline Residual effect & 0.2328 & & & \\
\hline
\end{tabular}


indirect effects. The direct effects of all secondary traits on production per plant were higher than the genetic correlations with production per plant, which indicates the existence of one or more traits, not considered in this study, that affect production per plant, mainly plant height, for which a change was observed in the direction of the correlation.

This explanation is supported by the fact that the coefficient of determination of the track analysis $\left(\mathrm{R}^{2}=0.1750\right)$ was very low. Therefore, it is clear that the variation in the main variable was not fully explained by this causal scheme (Table 4 ).

For the primary traits number of fruits and fruit mass, there were no direct or indirect effects of secondary variables of high magnitude that could exceed the respective residual effect (Table 5). This indicates that these secondary traits are not the main components of the variations observed in the primary variables, and that indirect selection was ineffective in these cases. It is observed that only plant height showed positive direct effect on the number of fruits
(0.5326). The other effects, both direct and indirect, were predominantly low and negative. Regarding fruit mass, the highest direct and indirect effects were found for the trait canopy volume. Plant height showed the highest negative direct effect on fruit mass $(-0.5903)$, with low indirect effect on stem diameter $(0.0808)$ and a mean indirect effect on canopy volume (0.5323).

The coefficients of determination of the track analysis of the direct and indirect effects of the secondary components on the two primary components $\left(\mathrm{R}^{2}=0.1891\right.$ and 0.1779 , respectively) were very low. Therefore, the variation in the main trait was not fully explained by this causal scheme (Table 5).

This fact was also corroborated by the estimates of the genetic parameters (Table 1), in which the three vegetative traits and fruit mass had low genetic variance and restricted individual heritabilities, with low average progeny base and plot, and low selective accuracy, which leads to low magnitude in cause and effect relationships between the genetic correlations deployed on path analysis. It is necessary that studies

Table 4. Estimates of the direct and indirect effects of secondary components of plant height, stem diameter and canopy volume on the main characteristic production per plant in guava tree (Psidium guajava).

\begin{tabular}{lccccc}
\hline Trait & Direct effect & & Indirect effect & \multicolumn{2}{c}{ Total } \\
\cline { 3 - 5 } & & Plant height & Stem diameter & Canopy volume & -0.0692 \\
Plant height & 0.4401 & - & -0.1662 & -0.3464 & -0.1618 \\
Stem diameter & -0.3050 & 0.2352 & - & - & -0.1220 \\
Canopy volume & -0.3879 & 0.3931 & -0.1272 & & \\
\hline $\mathrm{R}^{2}$ & 0.1750 & & & \\
Residual effect & 0.9550 & & & \\
\hline
\end{tabular}

Table 5. Estimates of the direct and indirect effects of the secondary components plant height, stem diameter, and canopy volume on the primary components: number of fruits per plant, and fruit mass in guava tree (Psidium guajava).

\begin{tabular}{|c|c|c|c|c|c|}
\hline \multirow[t]{2}{*}{ Trait } & \multirow[t]{2}{*}{ Direct effect } & \multicolumn{3}{|c|}{ Indirect effect } & \multirow[t]{2}{*}{ Total } \\
\hline & & Plant height & Stem diameter & Canopy volume & \\
\hline & & \multicolumn{4}{|c|}{ Number of fruits } \\
\hline Plant height & 0.5326 & - & -0.2136 & -0.3975 & -0.0785 \\
\hline Stem diameter & -0.3998 & 0.2846 & - & -0.1857 & -0.3009 \\
\hline Canopy volume & -0.4451 & 0.4757 & -0.1869 & - & -0.1362 \\
\hline $\mathrm{R}^{2}$ & 0.1891 & & & & \\
\hline \multirow[t]{2}{*}{ Residual effect } & 0.9078 & & & & \\
\hline & & \multicolumn{4}{|c|}{ Fruit mass } \\
\hline Plant height & -0.5903 & - & 0.0808 & 0.5323 & 0.0228 \\
\hline Stem diameter & 0.1513 & -0.3154 & - & 0.2486 & 0.0845 \\
\hline Canopy volume & 0.5960 & 0.4757 & 0.0631 & - & 0.1319 \\
\hline $\mathrm{R}^{2}$ & 0.1779 & & & & \\
\hline Residual effect & 0.9102 & & & & \\
\hline
\end{tabular}


on segregating progenies in guava trees include more traits related to the production components to increase selection efficiency in breeding programs. Rangel et al. (2011), in a study on popcorn, used path analysis and reported that secondary components are not necessarily the main causes of variations in primary variables.

Regarding the canonical correlations (Table 6), the first canonical pair showed correlation of 0.5970 , which allows inferring that the selection of more productive individuals and with higher number of fruits tends to reduce plant height, stem diameter and canopy volume. On the other hand, for the second canonical pair, with correlation of 0.4364 , plants with smaller stem diameter tend to provide lower production per plant. Therefore, for any of the canonical pairs considered for individual plant selection, it is possible to obtain simultaneous gains only for the traits number of fruits and production per plant, with the decrease of the other vegetative traits.

It is important to highlight that the decrease in the value of the vegetative traits, which may have resulted from the simultaneous selections for fruit production and number of fruits, was slight, since there was low genetic variation between the full-sib progenies (Table 1). These canonical coefficients are important for decision making in the stages of selection of superior individuals for the traits of interest when two different groups of traits are considered. However, for these groups, reproductive and vegetative, considered in this research, a low value of correlations in the

Table 6. Coefficients of canonical correlations and canonical pairs estimated between reproductive traits number of fruits, production per plant, and fruit mass; and the vegetative traits plant height, stem diameter, and canopy volume.

\begin{tabular}{lccc}
\hline Trait & \multicolumn{3}{c}{ Canonical pairs } \\
\cline { 2 - 4 } & $1^{\text {st }}$ & $2^{\text {nd }}$ & $3^{\text {rd }}$ \\
\hline \multirow{2}{*}{ Number of fruits } & 0.9013 & -0.2495 & -0.3540 \\
Production per plant & 0.8652 & -0.5012 & -0.0051 \\
Fruit mass & -0.1136 & -0.1477 & 0.9824 \\
\hline & & Vegetative \\
Plant height & -0.6495 & 0.1550 & -0.7443 \\
Stem diameter & -0.6862 & -0.5606 & -0.4632 \\
Canopy volume & -0.8881 & 0.2635 & -0.3765 \\
\hline R & 0.5970 & 0.4364 & 0.0528 \\
$\alpha(\%)$ & 84.1895 & 80.7705 & 88.4764 \\
\hline
\end{tabular}

first and the second canonical pairs considered was evidenced.

\section{Conclusions}

1. It is possible to obtain gains in selection both between and within full-sib progenies in guava tree (Psidium guajava).

2. It is difficult to obtain guava cultivars that associate high production per plant, fruit mass, and number of fruits.

3. The vegetative traits have little effect on fruit production, number of fruits, and fruit mass in guava tree.

\section{Acknowledgments}

To Coordenação de Aperfeiçoamento de Pessoal de Nível Superior (Capes) and to Fundação Carlos Chagas Filho de Amparo à Pesquisa do Estado do Rio de Janeiro (Faperj), for scholarships granted and financial support for the conduction of the experiment.

\section{References}

BEZERRA NETO, F.V.; LEAL, N.R.; COSTA, F.R.; GONÇALVES, G.M.; AMARAL JÚNIOR, A.T. do; VASCONCELOS, H.O.; MELLO, M. Análise biométrica de linhagens de abóbora. Horticultura Brasileira, v.24, p.378-380, 2006. DOI: 10.1590/S0102-05362006000300022.

CABRAL, P.D.S.; AMARAL JÚNIOR, A.T. do; FREITAS, I.L. de J.; RIBEIRO, R.M.; SILVA, T.R. da C. Relação causa e efeito de caracteres quantitativos sobre a capacidade de expansão do grão em milho-pipoca. Revista Ciência Agronômica, v.47, p.108-117, 2016.

CAMPOS, B.M.; VIANA, A.P.; QUINTAL, S.S.R.; GONÇALVES, L.S.A.; PESSANHA, P.G. de O. Quantificação da divergência genética entre acessos de goiabeira por meio da estratégia Ward-MLM. Revista Brasileira de Fruticultura, v.35, p.571-578, 2013. DOI: 10.1590/S0100-29452013000200028.

COIMBRA, J.L.M.; BENIN, G.; VIEIRA, E.A.; OLIVEIRA, A.C. de; CARVALHO, F.I.F.; GUIDOLIM, A.F.; SOARES, A.P. Consequências da multicolinearidade sobre a análise de trilha em canola. Ciência Rural, v.35, p.347-352, 2005. DOI: 10.1590/ S0103-84782005000200015.

CRUZ, C.D. GENES: a software package for analysis in experimental statistics and quantitative genetics. Acta Scientiarum. Agronomy, v.35, p.271-276, 2013. DOI: 10.4025/ actasciagron.v35i3.21251.

CRUZ, C.D.; REGAZZI, A.J.; CARNEIRO, P.C.S. Modelos Biométricos aplicados ao melhoramento genético. 4.ed. Viçosa: UFV, 2012. 514p. 
FALCONER, D.S.; MACKAY, T.F.C. Introduction to quantitative genetics. $4^{\text {th }}$ ed. London: Longman, 1996. 463p.

HENDERSON, C.R. Best linear unbiased estimation and prediction under a selection model. Biometrics, v.31, p.423-447, 1975. DOI: $10.2307 / 2529430$.

MARÇAL, T. de S.; FERREIRA, A.; OLIVEIRA, W.B. dos S.; GUILHEN, J.H.S.; FEREIRA, M.F. da S. Correlações genéticas e análise de trilha para caracteres de fruto da palmeira juçara. Revista Brasileira de Fruticultura, v.37, p.692-698, 2015. DOI: 10.1590/0100-2945-163/14.

MONTGOMERY, D.C.; PECK, E.A. Introduction to linear regression analysis. New York: John Wiley, 1981. 504p.

NATALE, W.; ROZANE, D.E.; SOUZA, H.A. de; AMORIM, D.A. de. (Ed.). Cultura da goiaba: do plantio à comercialização. Jaboticabal: Unesp-FCAV, 2009. v.2, p.407-428.

OLIVEIRA, E.J. de; LIMA, D.S. de; LUCENA, R.S.; MOTTA, T.B.N.; DANTAS, J.L.L. Correlações genéticas e análise de trilha para número de frutos comerciais por planta em mamoeiro. Pesquisa Agropecuária Brasileira, v.45, p.855-862, 2010. DOI: 10.1590/S0100-204X2010000800011.

PATTERSON, H.D.; THOMPSON, R. Recovery of inter-block information when block sizes are unequal. Biometrika, v.58, p.545-554, 1971. DOI: 10.1093/biomet/58.3.545.

PELEA, L.P.; GONZÁLEZ, A.S.; FERNÁNDEZ, E.B.; RODRÍGUEZ MEDINA, N.N.; VALDÉS-INFANTE HERRERO, J.; POMMER, C.V. Heritability estimates of guava (Psidium guajava L.) Agricultural important characters evaluated in three populations. Acta Horticulture, v.959, p.117-123, 2012. DOI: 10.17660/ActaHortic.2012.959.14.

PESSANHA, P.G. de O.; VIANA, A.P.; AMARAL JÚNIOR, A.T. do; SOUZA, R.M. de; TEIXEIRA, M.C.; PEREIRA, M.G. Avaliação da diversidade genética em acessos de Psidum spp. via marcadores moleculares RAPD. Revista Brasileira de Fruticultura, v.33, p.129-136, 2011. DOI: 10.1590/S010029452011000100018

POMMER, C.V.; MURAKAMI, K.R.N.; WATLINGTON, F. Goiaba no mundo. O Agronômico, v.58, p.22-26, 2006.

PRODUÇÃO AGRÍCOLA MUNICIPAL: culturas temporárias e permanentes. Rio de Janeiro: IBGE, v.40, 2013. Available at: $\quad<$ http://biblioteca.ibge.gov.br/visualizacao/periodicos/66/ pam_2013_v40_br.pdf>. Accessed on: Dec. 92015.

RANGEL, R.M.; AMARAL JÚNIOR, A.T. do; GONÇALVES, L.S.A.; FREITAS JÚNIOR, S. de P.; CANDIDO, L.S. Análise biométrica de ganhos por seleção em população de milhopipoca de quinto ciclo de seleção recorrente. Revista Ciência Agronômica, v.42, p.473-481, 2011. DOI: 10.1590/S1806-66902011000200029.

RESENDE, M.D.V. de. Matemática e estatística na análise de experimentos e no melhoramento genético. Colombo: Embrapa Florestas, 2007. 560p.

RESENDE, M.D.V. de. Software Selegen-REML/BLUP: a useful tool for plant breeding. Crop Breeding and Applied Biotechnology, v.16, p.330-339, 2016. DOI: 10.1590/1984-70332016v16n4a49.

RESENDE, M.D.V. de; DUARTE, J.B. Precisão e controle de qualidade em experimentos de avaliação de cultivares. Pesquisa Agropecuária Tropical, v.37, p.182-194, 2007.

SANTOS, E.A.; VIANA, A.P.; FREITAS, J.C. de O.; RODRIGUES, D.L.; TAVARES, R.F.; PAIVA, C.L.; SOUZA, M.M. Genotype selection by REML/BLUP methodology in a segregating population from an interspecific Passiflora spp. crossing. Euphytica, v.204, p.1-11, 2015. DOI: 10.1007/s10681015-1367-6.

SILVA, F.L. da; PEDROZO, C.A.; BARBOSA, M.H.P.; RESENDE, M.D.V.; PETERNELLI, L.A.; COSTA, P.M. de A.; VIEIRA, M.S. Análise de trilha para os componentes de produção de cana-de-açúcar via blup. Revista Ceres, v.56, p.308-314, 2009.

SOUZA, H.A. de; NATALE, W.; PRADO, R. de M.; ROZANE, D.E.; ROMUALDO, L.M.; HERNANDES, A. Efeito da calagem sobre o crescimento de goiabeiras. Revista Ceres, v.56, p.336$341,2009$.

TEIXEIRA, D.H.L.; OLIVEIRA, M. do S.P. de; GONÇALVES, F.M.A.; NUNES, J.A.R. Correlações genéticas e análise de trilha para componentes de produção de frutos de açaizeiro. Revista Brasileira de Fruticultura, v.34, p.1135-1142, 2012. DOI: 10.1590/S0100-29452012000400022.

VIANA, A.P.; RESENDE, M.D.V. de. Genética quantitativa no melhoramento de fruteiras. Rio de Janeiro: Interciência, 2014. 296 p. 